\title{
POTPISIVANJE JUGOSLOVENSKO-GRČKOG PROTOKOLA U OKTOBRU 1928. GODINE
}

\begin{abstract}
APSTRAKT: Razrešavanje grčko-jugoslovenskih razlika putem potpisivanja Protokola u Beogradu u oktobru 1928, kao uvod u ozvaničenje grčko-jugoslovenskog prijateljstva sklapanjem „Sporazuma o prijateljstvu, izmirenju i arbitraži“ od 27. marta 1929, predstavljalo je prelomnu tačku u odnosima (Kraljevine SHS) Jugoslavije i Grčke u hronološkim okvirima poslednje vlade grčkog premijera Elefteriosa Venizelosa.

Potpisivanje navedenih diplomatskih protokola uticalo je na razvoj događaja u prostoru jugoistočne Evrope, a ponovno oživljavanje intenzivnih diplomatskih odnosa između Kraljevine SHS i Grčke dalo je podstrek jednom opštem balkanskom sporazumu u nastupajućem periodu. Prikaz $i$ analiza procedure potpisivanja Protokola iz oktobra 1928. posebno upućuju na značaj političkih poteza grčkog premijera Venizelosa i njegovo protivljenje kolektivnom balkanskom sporazumu na račun sklapanja bilateralnih ugovora, kao i na promenu njegove spoljne politike posle približavanja Italiji.
\end{abstract}

Ključne reči: jugoslovensko-grčki odnosi, Protokol iz 1928, E. Venizelos, kralj Aleksandar Karađorđević

Analiza predistorije diplomatskih odnosa Kraljevine Jugoslavije i Grčke u periodu koji je prethodio zvaničnoj obnovi prijateljskih veza putem potpisivanja Protokola u Beogradu 1928. ukazuje na kompleksnost bilateralnih kontakata diplomatske osovine Atina-Beograd u periodu 1918-1928. Nesumnjiva promena u političkoj klimi između dve savezničke zemlje, koja može biti definisana kao zaokret u njihovim odnosima, primetna je od momenta ostvarivanja ideje ujedinjenja južnoslovenskih naroda u Kraljevinu Srba, Hrvata i Slovenaca 1918.

Iako je potpisivanje Ugovora o Savezu iz 1913. ograničavalo i onemogućavalo težnje i planove političkih vrhova dveju saveznica za ostvarivanje sop- 
stvenih teritorijalnih ciljeva na račun one druge, u jednoj kompleksnoj situaciji kao što je bila balkanska u periodu Prvog svetskog rata i određivanja granica na Balkanu, 1918. godina označila je raskid sa savezničkim tradicijama, kao i očigledno zahlađenje u međusobnim relacijama sve do oktobra 1928. Uprkos pokušajima da se konfliktna pitanja između dva suseda razreše putem brojnih pregovora, koji su uglavnom rezultirali dogovorima kratkog veka (,,Sporazum o uređenju tranzicione trgovine putem Soluna“ iz 1923, „Pangalosovi sporazumi“ iz 1926), tek je povratak Elefteriosa Venizelosa na vlast 1928. stvorio neophodne preduslove za korenito razjašnjavanje diplomatskih suprotnosti između dve susedne zemlje. Kao idejni tvorac grčko-srpskog saveza iz 1913, poklanjao je naročitu pažnju očuvanju prijateljskih odnosa sa severnim susedom Grčke. Zahvaljujući, pre svega, diplomatskoj veštini grčkog premijera, koji je potrebu za obnovom prijateljskih odnosa sa Kraljevinom SHS smatrao sastavnim delom svoje nove spoljne politike, karakterisane tendencijom sprovođenja mirovnih inicijativa na Balkanu, suštinska obnova diplomatskih odnosa dveju zemalja otpočela je u Beogradu u oktobru 1928. godine.

Ponovno diplomatsko približavanje Kraljevine SHS i Grčke, kao segment spoljnopolitičkih težnji balkanskih zemalja za uspostavljanjem novog poretka na Balkanu, predstavljeno njihovim nastojanjima da uspostave međudržavnu saradnju, uz tendencije udaljavanja od uticaja velikih sila, ostvareno je, pre svega, zahvaljujući intervenciji Elefteriosa Venizelosa, ali i jugoslovenskog kralja Aleksandra. Diplomatski potezi dvojice državnika, uprkos tome što su u velikoj meri bili uslovljeni stavovima velikih sila, odigrali su ključnu ulogu u jugoslovensko-grčkom zaokretu i uspostavljanju novog kursa međudržavne saradnje, koja je od tada krenula uzlaznom linijom.

Poredeći odnose Srbije i Grčke sa odnosima dveju zemalja i njihovih

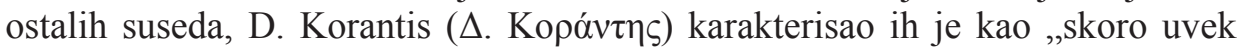
prijateljske“. ${ }^{1}$ Međutim, sklapanje „Protokola Politis-Kalfov“2 pretilo je da sudbinski ugrozi ,tradicionalno dobre grčko-jugoslovenske veze“. 3

Jugoslovenska vlada raskinula je 14. novembra 1924. grčko-srpski „Ugovor o savezu“. ${ }^{4}$ Opšti stav koji je preovladao mogao se svesti na tvrdnju da je

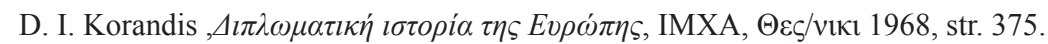

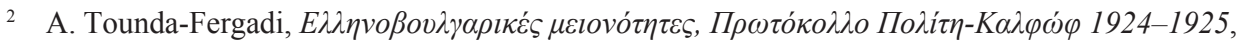

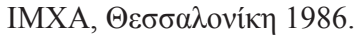

(Protokol „Politis-Kalfov“ potpisan je 24. 9. 1924 u Ženevi u okviru 5. redovnog zasedanja Društva naroda, a odnosio se na način primene odredbi o pitanjima manjina (Ugovor u Nejiju, 3. deo (27/11/1919), kao i Posebnog sporazuma iz Sevra (10/08/1920). U skladu sa članovima ovih ugovora Bugarska i Grčka preuzimale su na sebe obavezu o zaštiti svih nacionalnih manjina naseljenih na njihovim teritorijama).

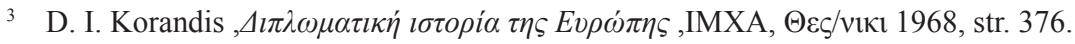

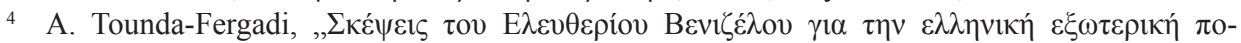

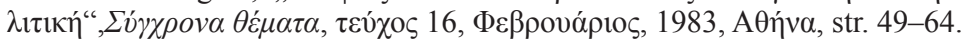


potpisivanje protokola između grčke i bugarske vlade predstavljalo neposredan povod za raskid ovog ugovora. Jugoslovenska vlada je smatrala neprihvatljivim odlučivanje o sudbini slavomakedonskog stanovništva isključivo putem dvostranih grčko-bugarskih pregovora. ${ }^{5}$ Suštinski uzrok treba, međutim, potražiti u promeni faktora koji su uslovili potpisivanje grčko-srpskog „Ugovora o savezu“ iz 1913.

Teritorijalno proširenje Kraljevine Srbije (od 1918. Kraljevine Srba, Hrvata i Slovenaca) dozvoljavalo je vlastima u Beogradu da vrše ,pritiske svake vrste" ${ }^{\text {"6 }}$ na Grčku, koja je u tom trenutku diplomatski bila skoro sasvim izolovana i iznutra oslabljena. Stalno su isticana četiri osnovna jugoslovenska zahteva, koje je Grčka pokušavala da ispuni u želji za ponovnim uspostavljanjem dobrih odnosa sa Kraljevinom SHS. Čineći ustupke shodno svom „potčinjenom“ položaju u odnosu na Kraljevinu, grčka strana je razmatrala: 1) ustupanje metoha manastira Hilandar; 2) sklapanje posebnog ugovora po pitanju manjina; 3) uređenje pitanja Slobodne carinske zone u Solunu, kao i 4) razrešenje pitanja načina funkcionisanja železničke linije Đevđelija-Solun. ${ }^{7}$

Nepohodno je primetiti da je na grčko-jugoslovenske odnose u datom momentu (pre svega na raskid Ugovora o savezu iz 1913) ${ }^{8}$ uticala i neizvesna pozicija Kraljevine SHS u balkanskom okruženju, koja je predstavljala direktnu posledicu politike Beograda prema Italiji, podložne neprekidnim izmenama, u skladu sa planovima italijanske politike na Balkanu. ${ }^{9}$

Tehnički sporazumi koji su pratili novopotpisani Sporazum između dve zemlje od 17. avgusta $1926 .{ }^{10}$ predviđali su proširenje srpske zone, značajno proširenje srpskih nadležnosti, kao i utvrđivanje mešovite komisije za kontrolisanje železničke linije Đevđelija-Solun. ${ }^{11}$ Međutim, reakcije grčkih političkih krugova na potpisani sporazum, koje su bile u skladu sa nezadovoljstvom i zahtevima javnog mnjenja, uslovile su svrgavanje vlade generala Pangalosa putem vojnog puča koji je izveo Kondilis. ${ }^{12}$ Posle zvaničnog opovrgavanja „Pangalosovih spo-

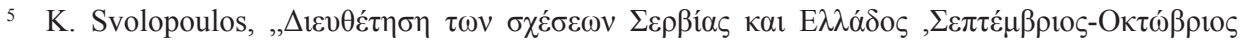

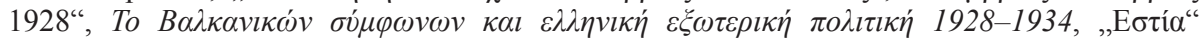

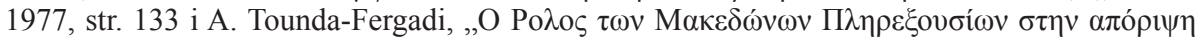

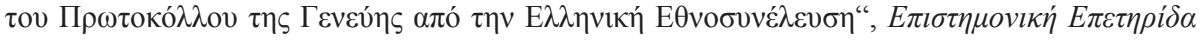
П.A.Е.П.Е., А $\theta \dot{v} v \alpha$ 1980, str. 598-603.

6 K. Svolopoulos, nav. delo, str. 134.

7 K. Svolopoulos, nav. delo, str. 135.

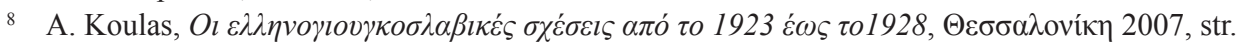
$58-73$.

9 D. I. Korandis, nav.delo, IMXA, $\Theta \varepsilon \varsigma /$ vıкı 1968, str. 136.

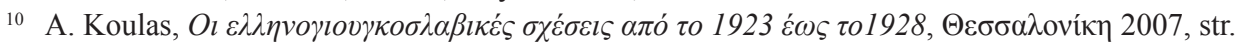
$170-178$.

11 J. Ancel, Les Balkans face a l'Italie, Paris 1928, str. 96.

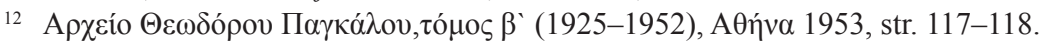


razuma“ na zasedanju grčke skupštine 25. avgusta 1927, dr Vojislav Marinković je naveo u svom izlaganju u skupštini da je obavestio Mihalakopoulosa o spremnosti Kraljevine SHS da otpočne pregovore o sklapanju jednog novog sporazuma između dve zemlje. ${ }^{13}$

Uprkos blagonaklonoj politici vlade Mihalakopulosa i primetnom poboljšanju u klimi grčko-jugoslovenskih odnosa, ali i nasuprot povoljnim reakcijama i prihvatanju politike grčkog premijera u jugoslovenskom javnom mnjenju, vlada u Beogradu nije pokazivala interesovanje za predloge Atine o obnavljanju pregovora. ${ }^{14}$ Međutim, potpisivanje jugoslovensko-francuskog sporazuma uslovilo je promenu stava zvaničnog Beograda, pa su polovinom oktobra vođeni pregovori o trgovinskom sporazumu između Kraljevine SHS i Grčke okončani uspehom. ${ }^{15}$ Krajem oktobra 1927. udružene vođe jugoslovenske opozicije Radić, Pribićević i Jovanović uputile su zahtev Marinkoviću za obrazloženje tadašnjeg spoljnopolitičkog položaja zemlje, posebno njenog odnosa prema Grčkoj i nastavka bilateralnih pregovora, ${ }^{16}$ na koji je ministar u tom trenutku odbio da odgovori, obećavajući da će dati adekvatno objašnjenje pošto bude proučio navedenu temu. $^{17}$

Odgovor Marinkovića, koji je usledio nešto kasnije, podstaknut dodatnim interesovanjem Ljubomira Nenadovića, obrazlagao je jugoslovenski stav upućujući na grčku argumentaciju o narušavanju njene nacionalne prevlasti i nerealne grčke zahteve kao glavne razloge za prekid otpočetih pregovora. ${ }^{18}$ Potpisivanje grčko-jugoslovenskog sporazuma o trgovini i pomorstvu $(2 / 11 / 1927)^{19}$ u trajanju od jedne godine označio je napredak u međusobnim odnosima. Pozitivna klima nije dugo prevladala, ${ }^{20}$ a početkom decembra 1927. zabeleženi su jugoslovenski

13 Times, 24/11/1927 u A. Koulas, nav. delo, str. 212.

14 A. Koulas, nav. delo, str. 219. (Trenutno raspoloženje jugoslovenske strane bilo je uslovljeno neizvesnošću paralelno izvođenih jugoslovensko-francuskih pregovora, uspešno okončanih 11/11/1927).

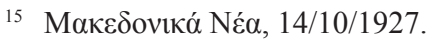

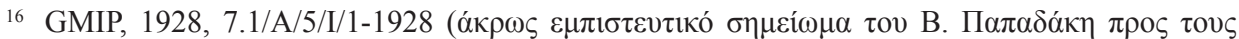

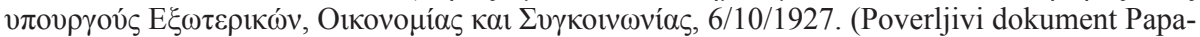
dakisa ministrima spoljnih poslova, ekonomije i saobraćaja upućivao je na zaključke o nerazrešenim međusobnim pravno-trgovinskim pitanjima prevlasti u oblasti Soluna, prisutnim još od 1923, koja su u slučaju nepravilnog tumačenja mogla biti iskorišćena u političke svrhe).

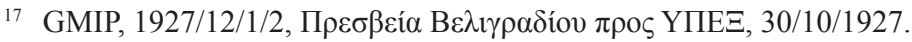

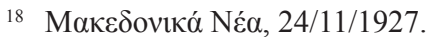

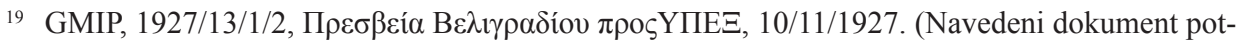
pisali su jugoslovenski predstavnici Popović i Kučić i grčki izaslanik Mihalakopoulos i Ksidakis na veliko zadovoljstvo jugoslovenske strane, videti Vreme, 4/11/1927).

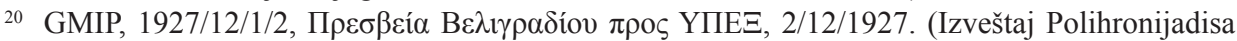
ukazivao je da jugoslovenska strana nije imala stvarnu nameru za sklapanje ugovora sa Atinom, u strahu da bi mogla izazvati stvaranje jednog italijansko-bugarskog antibloka. Vlada u Beogradu je smatrala, dodatno, da Grčka jedan ovakav savez želi kako bi ga iskoristila kao oružje protiv Bugarske, a navodi Polihronijadisa upućuju i na tendencije jugoslovenske strane za 
izazovi, ${ }^{21}$ koji su samo uvećali zabrinutost grčke strane uslovljavajući zahlađenje u međusobnim diplomatskim kontaktima.

Promenljiv stav Beograda uslovio je nužni zaokret u grčkoj politici i njen pokušaj da pre svega razreši svoje odnose sa Italijom. Ova grčka težnja, pak, pretila je da dobije različite, neočekivane političke razmere, kao i da bude pogrešno protumačena, naročito kod tadašnje vlade u Beogradu. Odluka o italijansko-grčko približavanju, bar u svome prvobitnom obliku, bila je potpuno suprotna planovima o grčko-jugoslovenskom zbližavanju. ${ }^{22}$

Pritisak jugoslovenske strane, iako nije predstavljao jedini odlučujući činilac, presudno je uticao na povoljni razvitak grčko-italijanskih odnosa. Napeta situacija koju je prouzrokovalo nepoverenje između jugoslovenske i italijanske strane doprinela je povoljnom razvitku pregovora između Atine i Rima tokom prve polovine 1928. godine. ${ }^{23}$

Postojanje mogućnosti potpisivanja najavljenog grčko-italijanskog ugovora sudbinski je podsticalo zabrinutost Beograda, dok je uzrok za odlaganje njegovog formalnog ozvaničenja trebalo potražiti i u strahu predsednika grčke vlade Mihalakopulosa da ne dođe u sukob sa diplomatskom osovinom BeogradPariz. $^{24}$

Ponovno pokretanje celokupnog problema jugoslovensko-grčkih odnosa podstakao je dolazak Elefteriosa Venizelosa na mesto premijera u junu 1928. Kao idejni tvorac grčko-srpskog saveza iz 1913. poklanjao je naročitu pažnju očuvanju prijateljskih odnosa sa severnim susedom Grčke. ${ }^{25}$ Ponovni dolazak Venizelosa na vlast, međutim, stvorio je neophodne preduslove za korenito razjašnjavanje diplomatskih suprotnosti sa zvaničnim Beogradom.

stvaranje srpsko-grčko-bugarskog sporazuma, kao protivargumenta za sklapanje dogovora samo sa Atinom.)

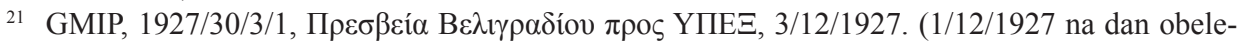
žavanja godišnjice stvaranja Kraljevine SHS, predsednik sokolskog društva uputio je pozdrav potčinjenoj braći u Istri, Grčkoj i Rumuniji).

22 K. Svolopoulos, nav. delo, str. 137-139.

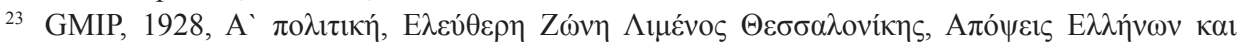

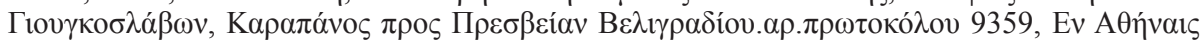

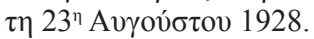

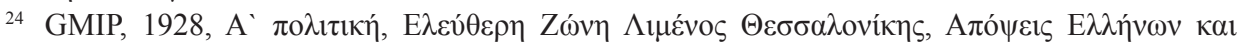

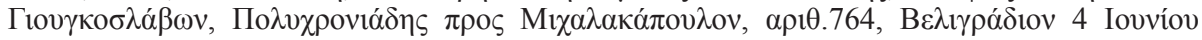

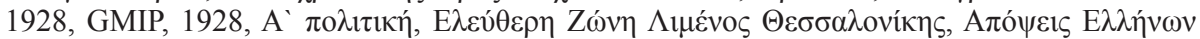

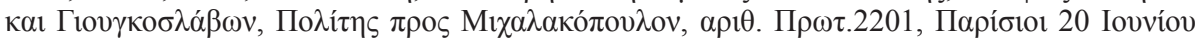

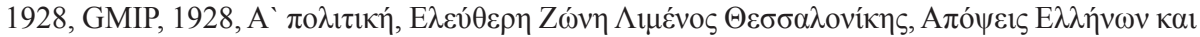

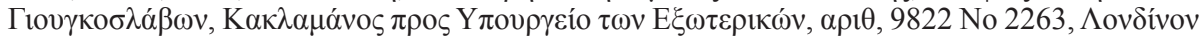
23/8/1928.

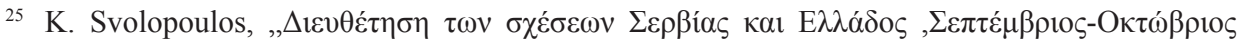

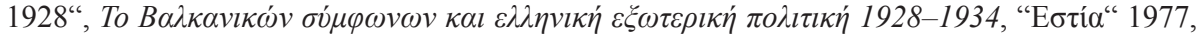
str. $133-135$. 
Kao nepokolebljivi zaštitnik grčko-srpskog saveza, premijer Venizelos je požurio da objavi predstojeći sporazum sa Italijom, kako u Parizu i u Londonu tako i u Beogradu, potvrđujući da sklapanje pomenutog sporazuma nipošto nije upravljeno protiv Kraljevine SHS. Paralelno, posredno utičući na pisanje međunarodne štampe, ali i posredstvom međunarodnih diplomatskih puteva, neprestano je podvlačio čvrstu nameru Atine da ponovo uspostavi klimu poverenja i prijateljstva sa susednom kraljevinom. On je odbacio predlog o sklapanju grčko-italijanskog saveza, izražavajući pri tom nemogućnost da sledi politiku koja bi mogla biti shvaćena kao neprijateljska prema jugoslovenskoj strani. Stav grčkog premijera upućivao je na stabilizovanje odnosa Atine i Beograda putem potpisivanja jednog sporazuma o nenapadanju, isključujući mogućnost potpisivanja dvostranog grčko-jugoslovenskog saveza. Besprekoran stav Venizelosa prema Beogradu ipak nije sprečio potpisivanje Grčko-italijanskog sporazuma od 23. septembra, čime je Italija značajno ojačala svoj uticaj u balkanskom prostoru, upravo na račun Jugoslavije. ${ }^{26}$

Inicijative za uređenje odnosa između Kraljevine SHS i Grčke, pre svega stav Francuske, jednog od odlučujućih činilaca za uspešno ostvarivanje procedure potpisivanja protokola između dva suseda, detaljno je pratila štampa ovog perioda, kao i prepiska između grčkih i srpskih diplomatskih predstavnika u Parizu i Beogradu. Reakcije francuske vlade na glasine o potpisivanju grčko-italijanskog sporazuma, zvanično su bile iskazane uverenjem francuskog premijera i ministra spoljnih poslova Brijana, posle razgovora koje je imao sa Marinkovićem, da potencijalno potpisivanje ovakvog sporazuma neće uticati na grčko-jugoslovenske pregovore o usklađivanju međusobnih odnosa. ${ }^{27}$

Značajan činilac koji je dodatno trebalo da ukaže na pozitivno raspoloženje obe susedne zemlje, na njihovo diplomatsko približenje, kao i na obostrani pokušaj razrešavanja pitanja koja su ih razdvajala, predstavljalo je osnivanje Grčko-srpskog sindikata u Solunu u periodu koji je neposredno prethodio potpisivanju konačnog sporazuma. Statut novoosnovanog Grčko-srpskog sindikata u Solunu uređivao je trgovinske odnose Kraljevine SHS i Grčke i utvrđivao njihove obaveze po pitanju Slobodne carinske zone u Solunu. ${ }^{28}$ Srdačnu manifestaciju grčko-srpskih odnosa u Privrednoj komori u Solunu prilikom osnivanja Grčko-srpskog sindikata komentarisao je francuski list Le Progress. Prenoseći mišljenje Mavrokordatosa, da je osnivanje jedne takve komisije moglo značajno da ojača prijateljske ali i trgovinske odnose dveju susednih zemalja, list je

26 K. Svolopoulos, nav. delo, str. 137-139.

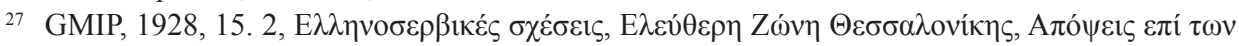

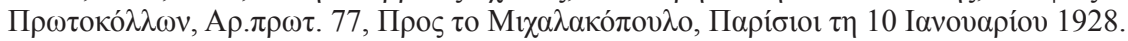

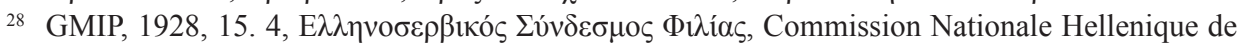
cooperation intelectuelle de la societe des nations, Athenes 10/04/1928. 
paralelno iznosio i stav Nastasijevića, predstavnika srpske strane, koji je delio mišljenje grčkog predstavnika. ${ }^{29}$

Solunski list Makedonija, pišući povodom osnivanja Grčko-srpskog sindikata, pored prikaza teške unutrašnje situacije u Jugoslavijii ${ }^{30}$ posle ubistva u Skupštini i reakcija hrvatske strane (,čije ponašanje ne uliva poverenje posle žalosnog događaja“"), izražavao je nadu da će osnivanje grčko-srpskog sindikata uspeti da izmeni ponašanje narodne mase koja je nadahnuta ,filologijom, pisanjem štampe i poezijom“ i da će ,doprineti postizanju suštinskih rezultata u poboljšanju odnosa dveju zemalja“. Osvrt na različite ekonomske interese dvaju suseda, kao i uverenje o suštinskoj izmeni srpskog stava prema Grčkoj u posleratnom periodu, članak je okončavao ubeđenjem da će grčko-srpski sindikat uspeti da ukloni nepoverenje i da preokrene postojeće neprijateljsko raspoloženje u odnosima dveju susednih zemalja. ${ }^{31}$ Journal de Geneve takođe je izveštavao o aktuelnoj grčko-jugoslovenskoj situaciji, naglašavajući pri tom ustupke Grčke prema Kraljevini. ${ }^{32}$

Potvrdu pozitivnih kretanja na osovini Atina-Beograd pruža članak „,Balkanski slučaj" lista Le Progress, prenoseći izjave jugoslovenskog ministra inostranih poslova Marinkovića povodom aktuelnih spoljnopolitičkih tema. Izražavajući pozitivno raspoloženje jugoslovenske strane za potpisivanje jednog sporazuma sa Grčkom koji bi uredio sva postojeća pitanja (pre svega ekonomske razlike), ministar je naglašavao tehničke poteškoće u izvođenju pregovora (pitanje slavomakedonskog stanovništva i njihov stav). ${ }^{33}$ Izražavajući, ipak, blagonakloni stav Beograda prema svom južnom susedu, navodio je da ,potpisivanje jednog grčko-italijanskog sporazuma ne bi trebalo da predstavlja prepreku za uspešno okončavanje odgovarajućih grčko-jugoslovenskih pregovora. ${ }^{\text {‘34 }}$

Pres-biro iz Soluna, prenoseći detalje razgovora Mavrokordatosa i generalnog konzula Kraljevine SHS Nastasijevića, naglašavao je neophodnost

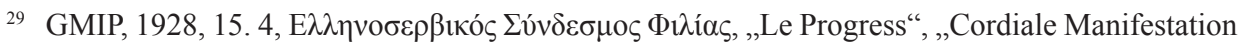
Greco-Serbe“, 4/09/1928.

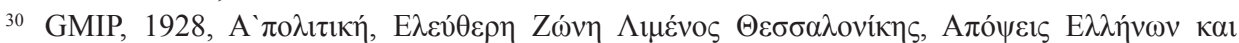

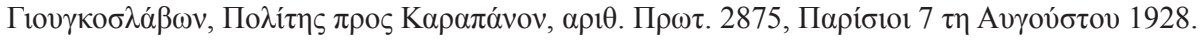

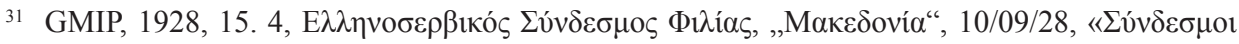

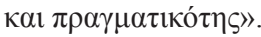

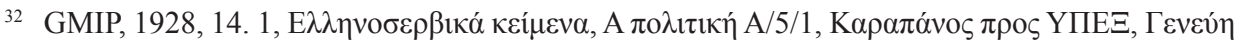
$10 / 09 / 1928$.

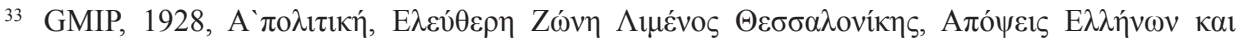

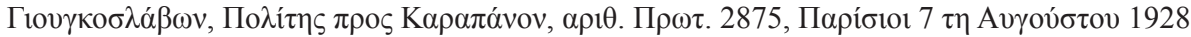
(„Politika koju je Jugoslavija primenjivala prema Grčkoj, a koja je zvanično težila usaglašavanju sa nama, sistematično je izbegavala ostvarivanje odavno izraženih tendencija, pisao je Politis Karapanosu").

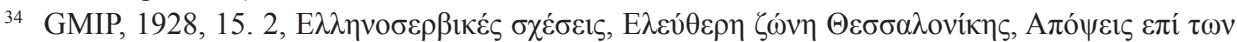

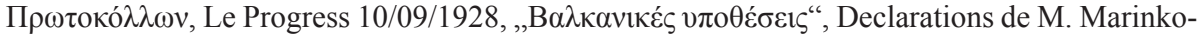
vitch sur la relation entre la Yougoslavie et la Grece. 
„izmene u srpskoj politici naspram Grčke“, pozitivno ocenjujući inicijativu za osnivanje grčko-srpskog sindikata u Solunu. ${ }^{35}$ Međutim, entuzijazam izražen pri osnivanju grčko-srpskog sindikata, prema rečima direktora biroa, bio je ,jednostran, iz razloga što je stav srpskih vlasti dijametralno različit od stava Srba prema Grcima“. 36

Analiza uslovljenosti grčko-jugoslovenskih odnosa stanjem na međunarodnoj sceni nužno je nametnula i ocenu odnosa Grčke i Francuske početkom 1928. Značajno je da ukažemo na zabrinutost francuske strane koju je prouzrokovao grčko-italijanski sporazum, kao i na taj način nastalu neravnotežu unutar sistema francuskih savezništava u istočnoj Evropi.

U periodu između dva svetska rata grčko-francuski odnosi došli su na probu u uslovima nove međunarodne stvarnosti, koju je određivao stav Ke d'Orseja. Diplomatska komunikacija između dve zemlje svoju najtežu fazu je prolazila upravo tokom prve polovine $1928 .{ }^{37}$ Razlozi za prevladavanje pomenute atmosfere nalazili su se $\mathrm{u}$ isplati ratnih reparacija i grčko-italijanskom približavanju, ali i u podršci koju je Italija pružala jugoslovenskim zahtevima naspram Grčke. Uistinu, od opovrgavanja grčko-srpskog saveza iz 1913, Ke d'Orse je uporno težio ponovnom zbližavanju Grčke i Srbije. Ponovni dolazak Venizelosa na vlast pružao je mogućnost za korenitu izmenu u odnosima Francuske i Grčke, kao i nadu da će njegovo prisustvo doprineti učvršćivanju mira u jugoistočnoj Evropi i brzom obnavljanju grčko-srpskih prijateljskih veza. ${ }^{38}$

Jugoslovenski izvori takođe su ukazivali na značaj dugoročnih grčko-srpskih pregovora za Ke d'Orse, naglašavajući da je u januaru 1928, buduće diplomatsko razrešenje odnosa dveju susednih zemalja bilo najznačajnije pitanje koje je interesovalo francusko ministarstvo inostranih poslova. Francuski diplomatski predstavnik Dar je preklinjao Marinkovića da nastavi sa pregovorima sa Grčkom, tvrdeći da će ovakav sporazum ojačati položaj Jugoslavije u njenim pregovorima sa Italijom. ${ }^{39}$

Francuska je insistirala da se razreši pitanje Soluna, kako bi se obezbedilo srpsko snabdevanje tokom rata, ali i kako Grčka ne bi našla utočište u Mu-

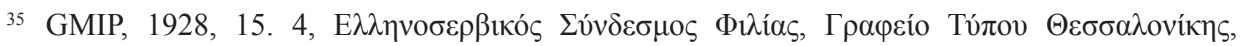
Ар.

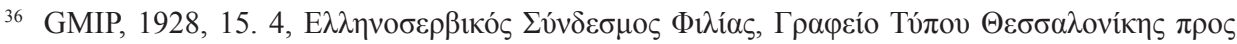

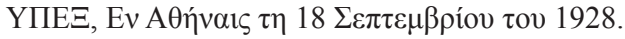

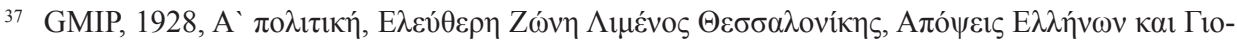

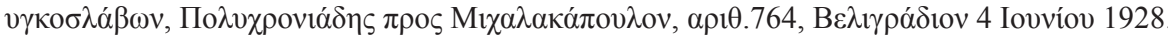

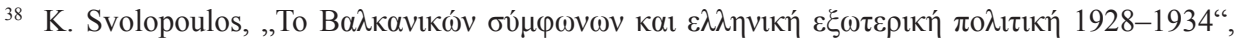

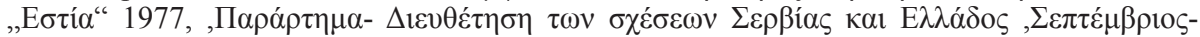

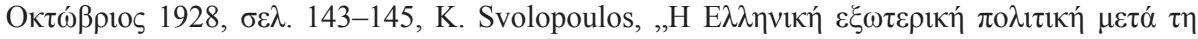

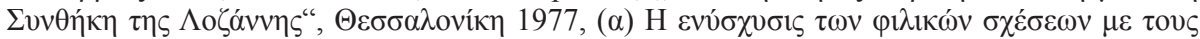

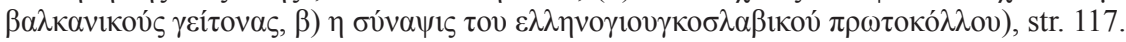

39 V. Vinaver, Jugoslavija i Francuska između dva rata, ISI, Beograd 1985, str. 134. 
solinijevom ,timu“. Grčka, baš kao i Jugoslavija, malo je pažnje obraćala na savete Francuske. Objašnjavajući ovu kriznu situaciju, V. Vinaver je naveo posetu Mihalakopulosa Musoliniju, citirajući pretnju grčkog izaslanika italijanskom izaslaniku Arlotti: „Ako sada uspostavite savezništvo sa Turskom, ja ću sklopiti jedan protokol sa Jugoslavijom“. ${ }^{40}$ Srpski izvori isticali su značaj ponovnog dolaska Venizelosa na vlast, a jugoslovenski predstavnici u Ženevi su govorili da će „lisica sa Krita znati da izvede manevar i sa Italijom i sa Jugoslavijom“, naglašavajući da ,Venizelos nije postao pion Musolinija, već naprotiv, Musolinija je iskoristio skoro kao svog piona da bi smirio Jugoslaviju“". ${ }^{11}$

Intervencija jugoslovenskog kralja Aleksandra značajno je doprinela obnavljanju pregovaračkih kontakata između Atine i Beograda. ${ }^{42}$ Tako je trećeg septembra, u Ženevi, objavljen početak pregovora između ministara spoljnih poslova obe zemlje, Karapanosa i Marinkovića. Nepokolebljivost predstavnika Kraljevine SHS i Grčke i njihova istrajnost u ostvarivanju postavljenih ciljeva nisu dozvoljavali pozitivan razvoj pregovora. Ke d'Orse je podsticao i naglašavao preko svog izaslanika u Beogradu korist za Kraljevinu ako nastavi sa pregovaračkim dijalogom i savetovao da se ne obeshrabruje pozitivno raspoloženje u Atini. ${ }^{43}$

Kako bi preokrenuo nezadovoljstvo i zabrinutost Francuske, Elefterios Venizelos je pristupio jednoj veoma retkoj egzibiciji svoje diplomatske veštine, obaveštavajući francusku stranu o toku pregovora sa italijanskom vladom. Konvencionalna forma grčko-italijanskog sporazuma izazivala je neposrednu rezervisanost Pariza, međutim, njen suštinski politički sadržaj, primenjivan u praksi, nije mogao predstavljati izvor zabrinutosti za francuske diplomatske krugove. Pokušaj Venizelosa da ostvari delimično prilagođavanje grčke spoljne politike, a da ne naruši pri tom sistem tradicionalno čvrstih veza saradnje i uzajamne podrške sa Francuskom i Velikom Britanijom pokazao se kao uspešan. Štaviše, uspeo je da iskoristi italijansku podršku kao argument u ublažavanju grčko-srpskih razlika, koje su predstavljale glavni predmet zabrinutosti i prepreku težnjama Ke d'Orseja u prostoru istočne Evrope.

40 V. Vinaver, nav. delo, str. 135.

41 V. Vinaver, nav. delo, str. 135.

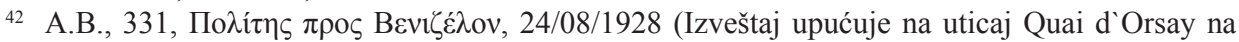

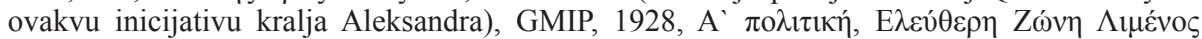

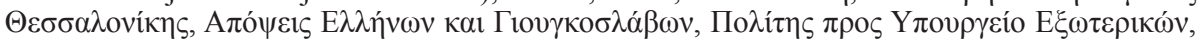
A renje Ph.Berthelota o isključivoj zasluzi Venizelosa za obnavljanje pregovaračkih konatakata Atine i Beograda, dok je sam Venizelos u svom izveštaju o toku pregovora u Beogradu naglašavao doprinos kralja Aleksandra povoljnom razvitku jugoslovensko-grčkih pregovora.) Videti

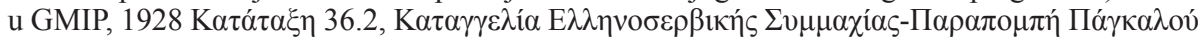

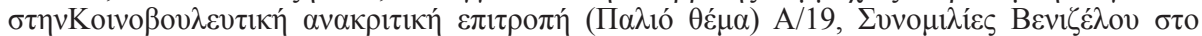

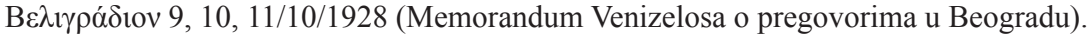

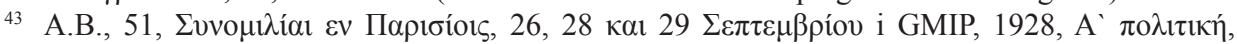

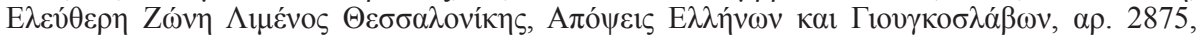

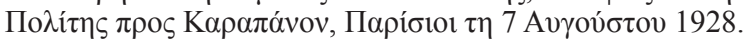


Razmatrajući osnovne negativne preduslove za potpisivanje jednog sporazuma sa Kraljevinom, tokom svojih razgovora sa Ke d'Orsejom, kao i u svojim pregovorima sa srpskim predstavnicima (Marinkovićem i Spalajkovićem), navodeći kao najvažnije preterane jugoslovenske zahteve, dodao je da je sklapanje jednog takvog sporazuma bilo nemoguće posle potpisivanja grčko-italijanskog sporazuma i da bi najverovatnije izazvalo ozbiljne posledice na veze Grčke i Italije, a takođe, da između Kraljevine SHS i Grčke ne postoji pitanje razlika u detaljima, već da su te razlike suštinske. ${ }^{44}$

U nastavku, kompromisno raspoloženje srpskih predstavnika, nametnuto od strane države i pruzrokovano mnogobrojnim činiocima, dozvolilo je povoljan nastavak pregovora. Unutrašnja kriza u Jugoslaviji (posle ubistva hrvatskih vođa 20. juna 1928, a koja je probudila nade Italije u mogući rascep Jugoslavije) podstakla je vladu da preduzme jednu diplomatsku inicijativu koja je bila primerena javnom mnjenju i osmišljena da izazove pozitivan odjek. Potpuno povlačenje Beograda pred grčkim stavovima bilo bi sumnjivo da nije bilo odlučujuće inicijative francuskog diplomatskog sistema, kao i direktne jugoslovenske zavisnosti od njega. ${ }^{45}$

Marinković je 29. septembra pregovarao sa premijerom Venizelosom povodom novog sporazuma. Venizelos je prihvatao potpisivanje jednog protokola u slučaju da se Bugarska ili neka od velikih sila okrene protiv balkanskog sistema, a koji Marinković nije prihvatao. Jugoslovenski predstavnik je na ovaj način bio primoran da se „cenjka“, koristeći francusko posredovanje. Paralelno, Venizelos je 23. septembra u Rimu potpisao grčko-italijanski sporazum o prijateljstvu i neutralnosti, nastavio svoj put prema Parizu, gde je podneo raport o svojoj politici „prema Rimu i Beogradu“, a zatim se 9. oktobra uputio prema Beogradu da bi nastavio svoje pregovore sa Marinkovićem. ${ }^{46}$

Novi razgovor Marinkovića sa Venizelosom 2. oktobra ukazivao je na mogućnost sklapanja ugovora o prijateljstvu i posredovanju između Grčke i Kraljevine, koji se ne bi suštinski razlikovao od grčko-italijanskog sporazuma. Objavljivanje uslova sadržanih u prvoj verziji sporazuma zapretilo je da izazove ozbiljne razmirice u većem delu srpskog javnog mnjenja. Osnovni uzrok nezadovoljstva ležao je ne toliko u načinu razrešavanja razlika po pitanju Soluna, već je to bio politički smisao sporazuma. Glavno pitanje jugoslovenske strane je bilo u osiguravanju jednog sporazuma obostranih garancija protiv mogućeg napada Bugarske kao saveznika neke treće strane, najverovatnije Italije. Sa druge strane, Venizelos je insistirao na potpisivanju jednostavnog sporazuma o prijateljstvu, koji je bio sličan onom potpisanom sa Italijom. ${ }^{47}$

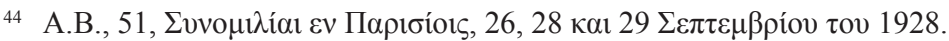

45 V. Vinaver, Jugoslavija i Francuska između dva rata, ISI, Beograd 1985, str. 148.

46 V. Vinaver, nav. delo, str. 147.

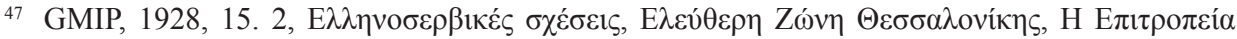

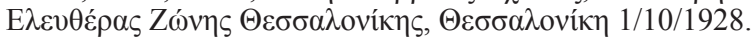


Pažljivo prateći efekte nove grčke spoljne politike, grčki diplomatski predstavnici detaljno su izveštavali o odjecima Venizelosove diplomatije na Balkanu. Prenoseći stav rumunskog pres-biroa o odnosu Venizelosa naspram Italije, kao i sagledavanje njegove balkanske vizije, koja se pored Kraljevine SHS odnosila i na Rumuniju, list Virtoul je naglašavao da grčki premijer nije bio pristalica ,balkanskog Lokarna“ i da je ovaj slučaj smatrao pitanjem budućnosti. Naročito je isticana uporna zainteresovanost Pariza za značenje sporazuma između Grčke i Italije. ${ }^{48}$

Nekoliko dana pre potpisivanja protokola u Beogradu, jedan zvaničan dokument upućen iz Poslanstva Kraljevine Srba Hrvata i Slovenaca u Atini, na ime Kalapotakisa, direktora pres-biroa u Atini, u izvesnoj meri potvrdio je oklevanje Beograda prenoseći stavove Marinkovića, ministra inostranih poslova Kraljevine SHS povodom sklapanja predstojećeg grčko-jugoslovenskog saveza. ${ }^{49}$

Uprkos nedefinisanosti zvaničnog jugoslovenskog stava, 9. oktobra 1928. premijer Grčke stigao je u Beograd povodom konačnih pregovora i potpisivanja protokola. Beogradska štampa (listovi Samouprava, Trgovinski glasnik, Vreme) prikazivali su dolazak grčkog premijera kao jedan prijatan i događaj od istorijskog značaja. ${ }^{50}$

Pregovori, koji su se odvijali u Beogradu tokom 9, 10. i 11. oktobra, zamalo nisu došli u bezizlaznu situaciju. Početni dogovor Venizelos-Marinković spasen je samo zahvaljujući odlučnoj reakciji kralja Aleksandra. ${ }^{51}$ Stav jugoslovenskog vladara može se objasniti ne samo njegovim iskrenim kompromisnim raspoloženjem, već i upornim francuskim preporukama. ${ }^{52}$ Tok kriznih pregovora u Beogradu, opisan u jednom opširnom memorandumu, izložio je lično grčki premijer. ${ }^{53}$ Marinković, posle potpisivanja grčko-italijanskog sporazuma, nije imao drugi izbor i bio je primoran da napravi kompromis sa zahtevima Francuske. Venizelos je ,izmanevrisao“ Marinkovića, pošto je sporazum sadržao i članak o neutralnosti Grčke. Grčka je na taj način ostajala neutralna u slučaju bilo kakvog

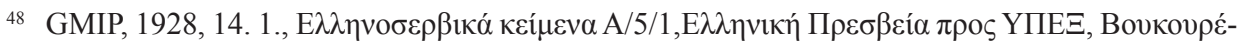
$\sigma \tau \imath, 1 / 10 / 1928$.

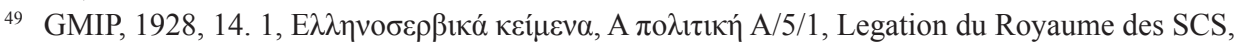
Athenes 4/10/1928.

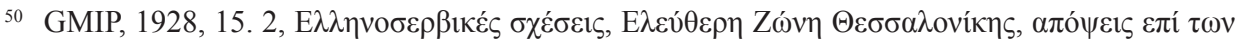
$\pi \rho \omega \tau$ око́ $\lambda \lambda \omega v, 9$ octobre, le press du Belgrade.

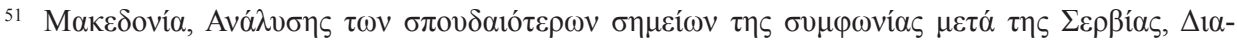

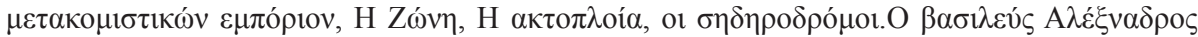

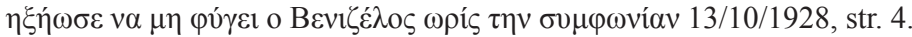

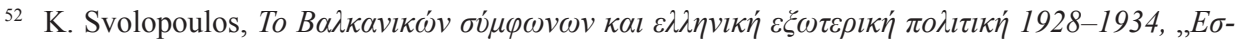

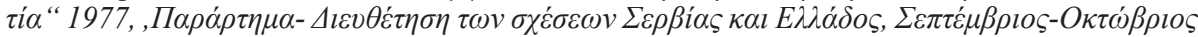

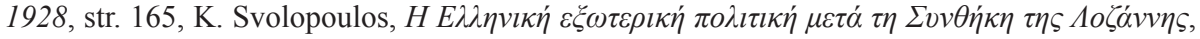
$\Theta \varepsilon \sigma \sigma \alpha \lambda$ ovíkך 1977, str. 132.

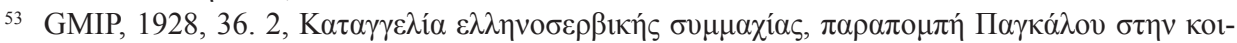

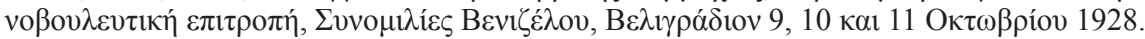


napada protiv Jugoslavije. Po želji Francuske, Venizelos se zakleo da ništa prikriveno nije postojalo u ugovoru sa Musolinijem, kao i da je kralj Aleksandar zvanično izjavio da nema nikakvih pretenzija prema Solunu. Venizelos je izrazio najveću zahvalnost Parizu, dok je Marinković bio primoran da ostane zadovoljan jednim sporazumom koji nije podrazumevao ni kontrolu železničke pruge niti tranzitnu trgovinu oružjem. ${ }^{54}$

Kompromisno raspoloženje srpskih predstavnika, koje je u suštini dozvoljavalo povoljan razvitak pregovora, bilo je podstaknuto od političkog vrha države kao posledica brojnih činilaca. Što se tiče unutrašnje političke situacije, rukovodeći krugovi, kao i jugoslovensko javno mnjenje, posle potpisivanja grčko-italijanskog sporazuma bili su savladani osećanjem da je Kraljevini pretilo da bude okružena jednim izolacionim obručem. Potpisivanjem grčko-italijanskog sporazuma, Grčka se priključila zemljama koje su održavale izuzetno bliske odnose sa Italijom (to su već bile učinile Mađarska i Bugarska). Njihov strah je bio pojačan činjenicom da, i pored otvorene diplomatije Venizelosa, nisu bili uvereni da se iza potpisivanja grčko-italijanskog protokola ne krije neka obaveza. Paralelno, pritisak poslovnih i ekonomskih krugova odlučno je podsticao jugoslovensku vladu na jedno kompromisno uređivanje razlika sa Grčkom. Ublažavanje ovih razlika, kao i uređivanje razlika sa preostalim susedima, bilo je postavljeno kao preduslov od zapadnoevropskih ekonomskih i političkih krugova za odobravanje jednog novog spoljnog zajma. Dodatno, unutrašnja politička kriza u Jugoslaviji podstakla je vladu na ovakvu diplomatsku inicijativu koja je trebalo da proizvede pozitivan odjek u javnom mnjenju. Naročito je Marinković u ovakvom nastupu jugoslovenske strane tragao za mogućnošću jačanja svoje lične pozicije. ${ }^{55}$

Konačno usaglašavanje stavova grčke i jugoslovenske vlade potvrđeno je putem Protokola od 11. oktobra. Ovaj protokol ne samo da je razjasnio postojeće nesuglasice (način funkcionisanja Slobodne zone u Solunu i železničke linije Solun-Đevđelija), ozvnačivši tako obnavljanje prijateljskih odnosa između Beograda i Atine, već je i otvorio put za potpisivanje protokola od 17. marta 1929, kojima je bila regulisana tranziciona trgovina preko Soluna, kao i prema „Sporazumu prijateljstva, pomirenja i arbitraže“ od 27. marta 1929.

Prema tvrdnji D. I. Korandisa, ova dva protokola potpisana u Beogradu razrešavala su glavne razlike između dve zemlje. Prvi protokol je predviđao da će pregovori između dveju zemalja biti podržani grčkim predlozima od 1. juna 1926. i da će biti rešena aktuelna pitanja: a) da će srpska zona u Solunu biti korišćena samo za transport robe prema Jugoslaviji i iz nje, a ne od neke treće strane ili pre-

54 V. Vinaver, Jugoslavija i Francuska između dva rata, ISI, Beograd 1985, str. 147.

55 V. Vinaver, Jugoslavija i Francuska između dva rata, ISI, Beograd 1985, str. 128; K. Svolo-

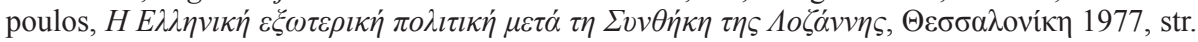
$132-136$. 
ma nekim trećim zemljama; b) da će brodovi koji se koriste u srpskoj slobodnoj zoni prethodno biti podvrgnuti higijenskoj kontroli grčkih vlasti i g) da se u srpskoj zoni zabranjuje industrijalizacija uvezene robe. Putem drugog protokola bilo je određeno da će u slučaju iskazivanja žalbi Kraljevine SHS koje bi se ticale funkcionisanja železničke linije Đevđelija-Solun, one biti prosleđivane na ocenu ličnosti odabrane od obe vlade. ${ }^{56}$

Razrešavanje grčko-srpskih razlika odlučno je doprinelo širenju saradnje u pravcu ostvarivanja mira u jugoistočnoj Evropi i ohrabrivalo je kretanje prema opštem balkanskom sporazumu. Uravnoteženje tendencija unutar balkanskog prostora, kao i verno prilagođavanje duhu Društva naroda, predstavljali su pozitivan doprinos u procesu ostvarivanja opšteg mira. Što se Venizelosa tiče, odgovarajuća primena njegovih diplomatskih veza sa Rimom, sa Parizom, kao i sa Londonom, pružala mu je sredstvo da slomi nepristupačnost Beograda. ${ }^{57}$

Potpisivanje Protokola od 11. oktobra je predstavljalo značajan uspeh za grčku diplomatiju. Zahvaljujući pre svega velikom diplomatskom iskustvu grčkog premijera, uspešno su bili povezani grčko-jugoslovenski dijalog i njegova šira evropska politika. Kao nosilac novog duha otvorene diplomatije, uspeo je da poveže zaokret prema Italiji, potvrdu prijateljstva prema Francuskoj i Velikoj Britaniji, kao i obnavljanje grčko-jugoslovenskih veza na osnovi ravnopravnosti i međusobnog poštovanja. ${ }^{58}$

Potpisivanje grčko-jugoslovenskih protokola je izazvalo višestruke reakcije i razgovore, o kojima svedoče novine i diplomatska prepiska odmah posle uređivanja odnosa u Beogradu. U prilog navedenoj činjenici navodimo izveštaj Polihronijadisa grčkom MIP-u, povodom potpisivanja protokola, koji naglašava značajne tačke kao što su:

1) Ograničavanje srpske zone isključivo na opsluživanje srpske trgovine,

2) Obaveza teretnih brodova da pri prolasku kroz srpsku zonu prilažu dokumenta prethodno overena od grčkih vlasti,

3) Postavljanje stanice u ovoj zoni,

4) Pitanje državljanstva monaha manastira Hilandar.

Po njegovom mišljenju, ovaj akt je prvobitno predstavljao osnov za reagovanje na mogućnost ponovnog ozvaničenja saradnje dve susedne zemlje.

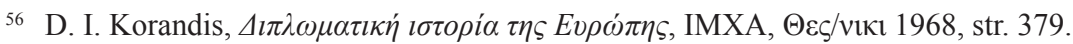

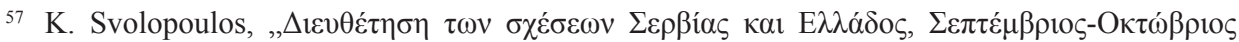

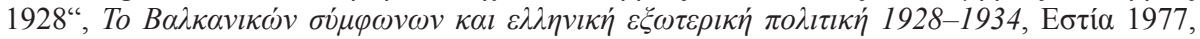

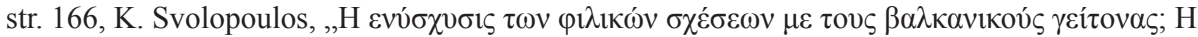

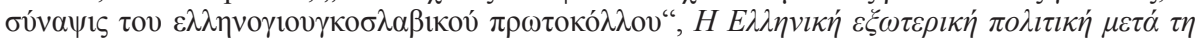

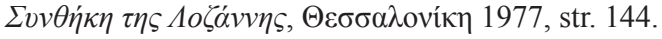

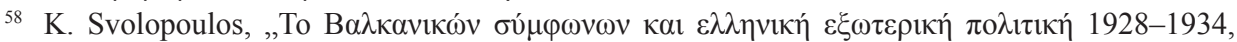

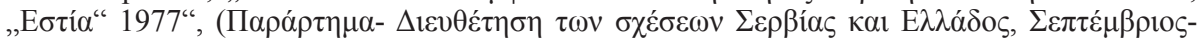

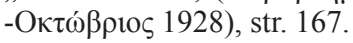


„Srbi““, koji su kao jedinu obavezu preuzeli na sebe tranzitnu trgovinu robom koja je bila namenjena Grčkoj, s druge strane su postavili zahteve koji su nailazili na otpor Grka (sopstvena železnička linija unutar zone, jugoslovensko državljanstvo za monahe na Hilandaru, pitanje osporavanog državljanstva). Ti zahtevi su na kraju napušteni, prenosio je grčki predstavnik u Beogradu. ${ }^{59}$

Le messager d'Athenes, kao potvrdu ublaženog stava Beograda, prenosio je pisanje jugoslovenske štampe. Opisujući susret zastupnika ministra inostranih poslova Kraljevine SHS Šumenkovića sa ministrima SAD-a, Rumunije i Velike Britanije, tokom kojeg je objavio potpisivanje protokola sa Venizelosom od 9, 10. i 11. oktobra, izjavio je da je njegova želja bila da se obnovi tradicionalno prijateljstvo sa Grčkom, kao i da se ponovo uspostavi mir na Balkanskom poluostrvu. List je naglašavao da je sporazum potpisan na čvrstoj osnovi koja obezbeđuje ,jedno trajno i korisno prijateljstvo“. Drugi članak istih novina prenosio je izjave koje je dao Venizelos posle svog povratka u zemlju, jedan opširan izveštaj o potpisanom protokolu, kao i sličnost grčko-jugoslovenskog protokola mogućeg trajanja i do pet godina, sa nedavno potpisanim grčko-italijanskim protokolom. $^{60}$

Italijanski list Tribuna, navodeći činjenice o sklopljenom sporazumu između Atine i Beograda, potpisivanje sporazuma opisivao je kao uspeh Grčke. Vrednost ugovora, prema pisanju lista, bila je u tome što je uspeo da neutrališe srpske zahteve koji su ugrožavali grčka prava, a koja su „Pangalosovi ugovori“ odobravali. Postojeći sporazum u potpunosti je bio primeren novoj grčkoj spoljnoj politici, koja je prema pisanju članka uspela da stvori osnove za potpis sporazuma sa Italijom. Ova politika trebalo je da bude krunisana budućim potpisivanjem ugovora sa Bugarskom i Turskom. Pisac članka optuživao je jugoslovensku politiku, koja je u saradnji sa Francuskom pokušala da Grčku privuče ka jednom antiitalijanskom bloku. ${ }^{61}$

Grčki listovi Fos, Tahidromos i Makedonija naročito su analizirali izjave Caldarisa povodom potpisanog grčko-jugoslovenskog sporazuma. On je izbegavao da bude jasan u prognozi budućih diplomatskih dešavanja na relaciji AtinaBeograd, navodeći samo sledeće: „Nemam u vidu samo uslove pod kojima će biti potpisan sporazum saradnje i prijateljstva sa Srbima, Hrvatima i Slovencima. Ne želim da iznosim sud po pitanju spoljne politike pre nego što budem imao precizan uvid u stanje. Jedino što sam u mogućnosti da kažem, jeste da među svim narodima preovladava težnja za mirom posle nesreća velikog rata. Sa tim

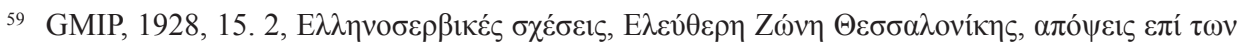
$\pi \rho \omega \tau$ ко $\lambda \lambda \omega v, 13 / 10 / 1928$.

60 Le messager d'Athenes, „Les dernieres Nouvelles, L`accord Greco-serbe et les Puissances, M. Venizelos rentre ce matin a Athenes, les declarations qu'il faites dans la nuit a Salonique“, $13 / 10 / 1928$.

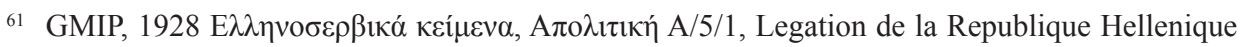

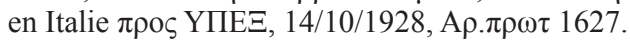


se grčki narod ne slaže u potpunosti. Sa opštim mišljenjem naroda slagala se i grčka vlada, a Ekumenski patrijarhat je težio da bude na usluzi politici mira, u naročitom cilju da se regulišu bitna pitanja sa Jugoslavijom, što je bio neophodan preduslov kako su stvari nalagale“".62

Članak u Neue freie presse analizirao je boravak Venizelosa u Beogradu tokom trajanja pregovora. List je pružao osvrt na razvojni put grčkog premijera u ostvarivanju njegove „,balkanske politike“, ne zaboravljajući da naglasi njegove zasluge za uređivanje odnosa između Grčke i Italije. Isti članak prenosio je i stavove bivšeg ministra spoljnih poslova Kraljevine SHS Ninčića, koji je komentarišući važnost Soluna naglašavao da on za Srbe nije bio toliko važan u trgovinskom smislu koliko kao zajednička stavka između prijatelja i saveznika u slučaju međunarodnih zapleta. Uprkos potpisivanju protokola između Kraljevine i Grčke, pitanje između dve zemlje je i dalje ostajalo otvoreno, prema njegovom mišljenju. U nastavku list je prenosio da je jugoslovensko rukovodstvo bilo primorano da prihvati rešenja koje se nisu poklapala sa njegovim interesima. Očigledno je iz tog razloga Venizelos iz Beograda otišao za Pariz. Pisac članka navodio je i negiranje Marinkovića o davanju predloga Venizelosu za sklapanje jednog savezničkog ugovora, koji je grčki premijer odbacio. ${ }^{63}$

Neophodno je da primetimo da je prepiska između grčkih diplomatskih predstavništava u Londonu, Parizu, Rimu i Beogradu sa grčkim MIP-om neobično bogata u periodu neposredno po potpisivanju Protokola u Beogradu. Dolazimo do zaključka da je uspešan nastavak implementacije nove grčke spoljne politike, zvanično otpočet povratkom Elefteriosa Venizelosa na mesto premijera, probudio sa jedne strane odobravanja, a sa druge zabrinutost velikih evropskih sila. Sigurno je, međutim, da je obnova grčko-jugoslovenskih prijateljskih odnosa stvarala jedan novi podsticaj i drugačije osnove za novu preraspodelu snaga i van uskih balkanskih okvira. ${ }^{64}$

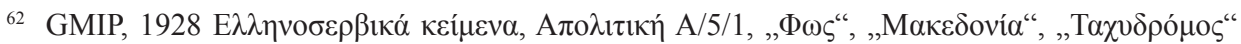
$14 / 10 / 1928$.

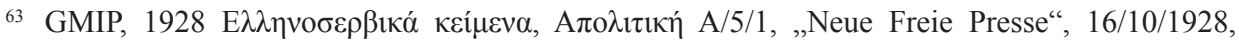

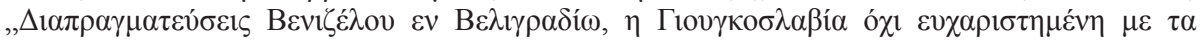
$\alpha \pi \mathrm{\alpha} \varepsilon \lambda \varepsilon_{\varepsilon} \sigma \mu \alpha \tau \alpha^{\prime \prime}$.

${ }^{64}$ Zvanična diplomatska prepiska karakteristična za period pripremanja beogradskih protokola, kao i reakcije koje je njihovo potpisivanje izazvalo među saveznicima, ali i protivnicima dve susedne zemlje veoma je bogata, a upućuje na značaj obnove prijateljskih odnosa dveju

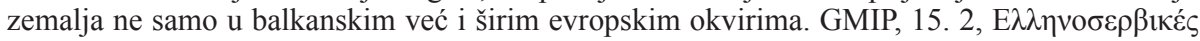

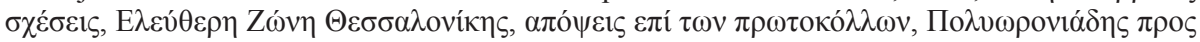

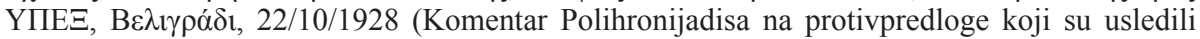

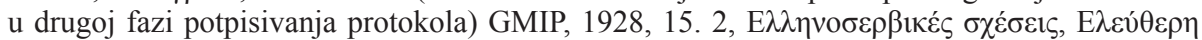

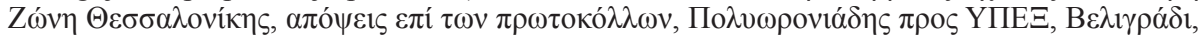
31/10/1928 (Obaveštenje Polihronijadisa o stizanju srpskih predloga povodom protokola)

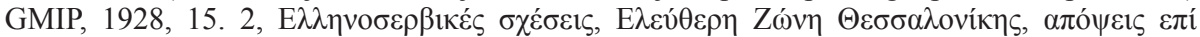

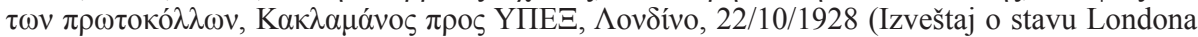
o potpisivanju grčko-jugoslovenskog protokola. Ovaj dokument se takođe odnosi na moguće 


\title{
Summary
}

\author{
M. A. Aleksandra Pećinar
}

\section{Signing of the Yugoslav-Greek Protocol in October 1928}

Key words: Yugoslav-Greek relations, The Protocol of 1928, E. Venizelos, King Aleksandar Karađorđević

Diplomatic rapprochement between Kingdoms of the Serbs, Croats and Slovenes and Greece that materialized in the signing of the 1928 Protocol, undoubtedly contributed to the endeavors to establish the new order in the Balkans that was represented by aspirations of the Balkan countries to establish mutual international cooperation coupled with their tendencies to avoid the Great Powers' influence. The obvious change in the diplomatic communication between the Kingdoms of the Serbs, Croats and Slovenes and Greece was realized after the solution of the conflicting issues had been reached, which separated the two

potpisivanje protokola sa Bugarskom, kao i na ideju stvaranja jednog „Balkanskog Lokarna“).

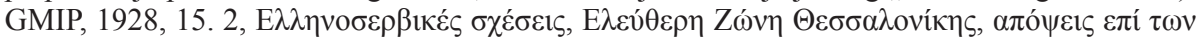

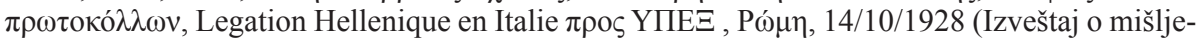
nju Grandija propraćen njegovim komentarima o zadovoljstvu italijanske vlade povodom uspeha Grčke u potpisivanju grčko-srpskog protokola, kao i molba da bude informisan o nastavku nji-

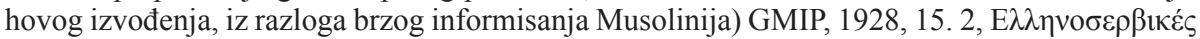

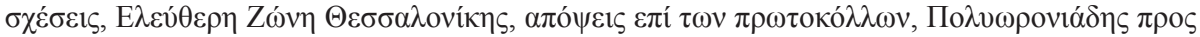

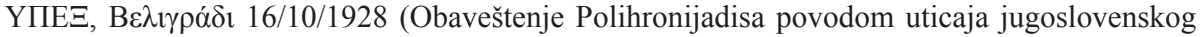
kralja na natpise u jugoslovenskoj štampi, kao i preporuka za pažljive izjave u grčkoj štampi

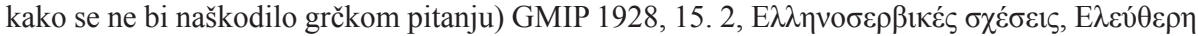
Z

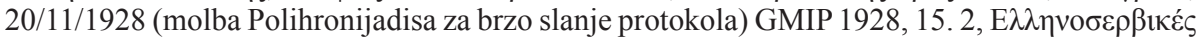

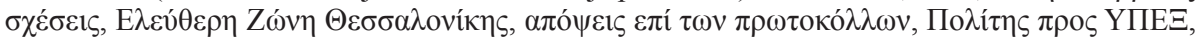
Парíбı, 11/11/1928 (Obaveštenje Politisa o razgovoru i ručku koji je imao sa jugoslovesnkim kraljem, molba jugoslovenskog kralja za informisanje o toku pregovora, iznenađenost povodom tema nesuglasica, kao i obećanje da će se posle svog povratka u Beograd pobrinuti da

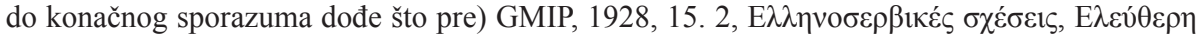

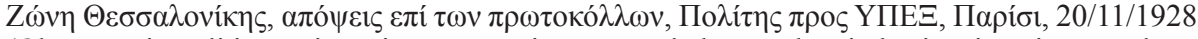
(Obaveštenje Politisa o njegovim razgovorima sa Berthelet-om, kao i ukazivanje Briana srpskom kralju za izvođenje pregovora $u$ duhu potpunog poverenja, koji bi trebalo da se izvedu u jednom

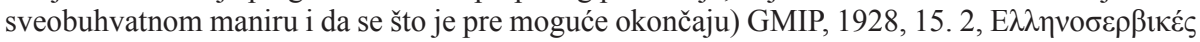

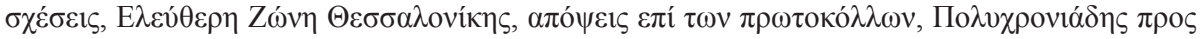

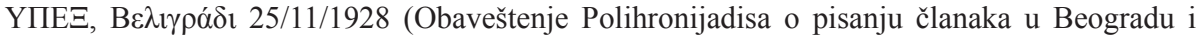
optimistična predviđanja povodom grčko-jugoslovenskog ugovora. Takođe, izveštaj o promeni na mestu ministra spoljnih poslova. U skladu sa njegovim izveštajem, Šumenković preuzima na sebe izvođenje pregovora umesto Marinkovića. U nastavku, obaveštenje da je protokole lično primio). 
countries throughout the prehistory of their diplomatic relations. Despite the remarkable influence that the Great Powers had on them, the diplomatic initiatives of the official representatives of the two countries (Eleftherios Venizelos and Alexandar Karađorđević, King of Yugoslavia), played the crucial role in GrecoYugoslav diplomatic shift, but also in establishing the new course in international cooperation.

A moderate change in the Greek attitude to the Great Powers had as its direct consequence the toning down of differences between Belgrade and Athens. The Treaty between Greece and Italy, as well as diplomacy of Greek Prime Minister, decisively influenced the positive outcome of negotiations with the Kingdom of SCS, contributing in that way to the already mentioned restoration of the Greek diplomatic influence in the Southeastern Europe, as well as to that country's exit from the diplomatic isolation, in which it had remained after the expedition to Izmir and the catastrophe in Asia Minor in 1922.

Despite the fact that the rapprochement between Greece and Yugoslavia represented a single step in the process of implementation of initiatives for the new peace policy in the Balkans, its importance in the change of the established balance between French and Italian systems of treaties, was very important.

Resolution of relations between the Kingdom of SCS and Greece, as well as the signing of the treaty between Greece and Italy, represented a significant factor, as well as the basis for the restoration of the Greek negotiating influence in the Balkans.

The signing of the Protocol of 1928 represented the beginning of the golden age, that lasted for the last four years of the Elefherios Venizelos's Government. 